\title{
The Flavin-Containing Monooxygenase 3 Gene and Essential Hypertension: The Joint Effect of Polymorphism E158K and Cigarette Smoking on Disease Susceptibility
}

\author{
Olga Bushueva, ${ }^{1}$ Maria Solodilova, ${ }^{1}$ Mikhail Churnosov, ${ }^{2}$ \\ Vladimir Ivanov, ${ }^{1}$ and Alexey Polonikov ${ }^{1}$ \\ ${ }^{1}$ Department of Biology, Medical Genetics and Ecology, Kursk State Medical University, Karl Marx Street, 3, Kursk 305041, Russia \\ ${ }^{2}$ Department of Medical Biological Disciplines, Belgorod State National Research University, Pobeda Street, 85, Belgorod 308015, Russia
}

Correspondence should be addressed to Olga Bushueva; olga.bushueva@inbox.ru

Received 11 June 2014; Revised 1 August 2014; Accepted 17 August 2014; Published 27 August 2014

Academic Editor: Franco Veglio

Copyright (c) 2014 Olga Bushueva et al. This is an open access article distributed under the Creative Commons Attribution License, which permits unrestricted use, distribution, and reproduction in any medium, provided the original work is properly cited.

Gene encoding flavin-containing monooxygenase 3 (FMO3), a microsomal antioxidant defense enzyme, has been suggested to contribute to essential hypertension $(\mathrm{EH})$. The present study was designed to investigate whether common functional polymorphism E158K (rs2266782) of the FMO3 gene is associated with EH susceptibility in a Russian population. A total of 2995 unrelated subjects from Kursk (1362 EH patients and 843 healthy controls) and Belgorod (357 EH patients and 422 population controls) regions of Central Russia were recruited for this study. DNA samples from all study participants were genotyped for the FMO3 gene polymorphism through PCR followed by RFLP analysis. We found that the polymorphism E158K is associated with increased risk of essential hypertension in both discovery population from Kursk region (OR 1.36 95\% CI 1.09-1.69, $P=0.01$ ) and replication population from Belgorod region (OR $1.5495 \%$ CI 1.07-1.89, $P=0.02$ ) after adjustment for gender and age using logistic regression analysis. Further analysis showed that the increased hypertension risk in carriers of genotype 158KK gene occurred in cigarette smokers, whereas nonsmoker carriers of this genotype did not show the disease risk. This is the first study reporting the association of the FMO3 gene polymorphism and the risk of essential hypertension.

\section{Introduction}

Oxidative stress resulting from the enhanced production of reactive oxygen species (ROS) and decreased activity of antioxidant defense enzymes has been implicated in pathogenesis of essential hypertension (EH) $[1,2]$. The flavin-containing monooxygenase 3 (FMO3) is a microsomal antioxidant defense enzyme involving the NADPHdependent oxygenation of a variety of nucleophilic xenobiotics possessing oxidant capacity [3]. Mutations in the FMO3 gene have been found to contribute to the disease trimethylaminuria (TMAuria), an inborn error of metabolism resulting from diminished oxidation of the tertiary amine trimethylamine to trimethylamine $\mathrm{N}$-oxide resulting in a severe body odour in affected individuals [4]. Interestingly, this genetic disorder is thought to be associated with risk of hypertension because patients with TMAuria have idiopathic hypertension $[4,5]$.

A single study investigated the relationship between common polymorphisms of the FMO3 gene and hypertension in Irish population [6]. However, these researchers found that none of the FMO3 gene polymorphisms was associated with hypertension risk. This negative result can be explained by a relatively low statistical power which is related with a small sample size in the study. The present study was designed to investigate whether common functional polymorphism E158K (rs2266782) of the FMO3 gene is associated with susceptibility to essential hypertension in Russia. Pursuing this aim, two independent populations of ethnic Russians from Kursk and Belgorod regions of Central Russia were included in this study to be used as discovery and replication cohorts, respectively. 
TABLE 1: Baseline characteristics of two study populations.

\begin{tabular}{|c|c|c|c|}
\hline Baseline characteristics & EH patients & Controls & $P$ values \\
\hline \multicolumn{4}{|c|}{ Discovery cohort (Kursk region): $1362 \mathrm{EH}$ patients and 843 healthy subjects } \\
\hline Age, mean \pm standard deviation & $56.4 \pm 10.4$ & $55.8 \pm 8.8$ & 0.18 \\
\hline $\begin{array}{l}\text { Gender } \\
\text { (M-male, F-female) }\end{array}$ & $\begin{array}{l}711 \mathrm{M}(52.2 \%) \\
651 \mathrm{~F}(47.8 \%)\end{array}$ & $\begin{array}{l}406 \mathrm{M}(48.2 \%) \\
437 \mathrm{~F}(51.8 \%)\end{array}$ & 0.07 \\
\hline $\begin{array}{l}\text { Body mass index } \\
\left(\mathrm{kg} / \mathrm{m}^{2}\right), \text { mean } \pm \text { standard deviation }\end{array}$ & $27.3 \pm 6.5$ & $26.2 \pm 5.9$ & $0.002^{*}$ \\
\hline $\begin{array}{l}\text { Family history } \\
\text { of hypertension }\end{array}$ & $\begin{array}{l}\text { Yes } 764(65.9 \%) \\
\text { No } 395(34.1 \%)\end{array}$ & $\begin{array}{l}\text { Yes } 414(57.8 \%) \\
\text { No } 302(42.2 \%)\end{array}$ & $0.0004^{*}$ \\
\hline Smoking status & $\begin{array}{l}\text { Yes } 841(67.4 \%) \\
\text { No } 406(32.6 \%)\end{array}$ & $\begin{array}{l}\text { Yes } 483(61.9 \%) \\
\text { No } 297(38.1 \%)\end{array}$ & $0.01^{*}$ \\
\hline \multicolumn{4}{|c|}{ Replication cohort (Belgorod region): $357 \mathrm{EH}$ patients and 422 population controls } \\
\hline Age, mean \pm standard deviation & $58.4 \pm 9.5$ & $57.3 \pm 10.2$ & 0.12 \\
\hline $\begin{array}{l}\text { Gender } \\
\text { (M-male, F-female) }\end{array}$ & $\begin{array}{l}211 \mathrm{M}(59.1 \%) \\
146 \mathrm{~F}(40.9 \%)\end{array}$ & $\begin{array}{l}267 \mathrm{M}(63.3 \%) \\
155 \mathrm{~F}(36.7 \%)\end{array}$ & 0.23 \\
\hline $\begin{array}{l}\text { Body mass index } \\
\left(\mathrm{kg} / \mathrm{m}^{2}\right), \text { mean } \pm \text { standard deviation }\end{array}$ & $26.2 \pm 4.8$ & $25.6 \pm 3.9$ & 0.07 \\
\hline $\begin{array}{l}\text { Family history } \\
\text { of hypertension }\end{array}$ & NA & NA & - \\
\hline Smoking status & NA & NA & - \\
\hline
\end{tabular}

${ }^{*}$ Means a significant difference between the groups.

\section{Materials and Methods}

The study was approved by Ethical Review Committee of Kursk State Medical University. A total of 2995 Russian unrelated subjects from Kursk (discovery cohort) and Belgorod (replication population) regions of Central Russia were included in the study. The discovery cohort comprising 2216 subjects (1362 EH patients and 843 healthy subjects with normal blood pressure) was recruited at Cardiology Clinics of Kursk Regional Clinical Hospital and Neurology Clinics of Kursk Emergency Medicine Hospital over two periods: between 2003 and 2006 [7] and between 2010 and 2013. The replication population included DNA samples from 779 individuals (357 $\mathrm{EH}$ patients and 422 population controls) which have been obtained from the biobank of Belgorod State National Research University, as part of a large population-based study of Belgorod region [8]. The baseline characteristics of the study patients are listed in Table 1. As can be seen from Table 1, hypertensive patients were matched to controls on sex and age $(P>0.05)$. Diagnosis of essential hypertension in both populations was verified by qualified cardiologists. Individuals were defined as hypertensive according to World Health Organization criteria or if they had a history of receiving any antihypertensive drug. Diagnosis of $\mathrm{EH}$ in untreated patients was defined by a seated systolic and/or diastolic blood pressure greater than 140 and/or $90 \mathrm{mmHg}$, respectively, on at least 2 separate measurements. All EH patients had no clinical signs, symptoms, and laboratory findings suggestive of secondary hypertension.

Genomic DNA was isolated from peripheral blood samples using a standard phenol/chloroform procedure. Genotyping of polymorphism E158K of the FMO3 gene was done using PCR followed by RFLP analysis as described elsewhere [9]. The genotyping results were scored by two independent investigators blindly to the patient's case/control status and regenotyping of about $5 \%$ of randomly selected samples yielded $100 \%$ reproducibility.

The association between the polymorphism and hypertension risk was estimated by odds ratio (OR) with 95\% confidence interval (CI) using multiple logistic regression analysis with adjustment for confounding variables such as age and gender. Each FMO3 genotype was assessed according to dominant, recessive, and additive genetic models, and the chi-squire (Wald's statistic) odds ratio with $95 \%$ confidence interval was calculated. Odds ratios were calculated as a measure of the association of the FMO3 genotype with hypertension risk, with the effects of the allele $158 \mathrm{~K}$ assumed to be additive (with scores of 0,1 , and 2 assigned for EE, $\mathrm{EK}$, and KK genotypes, resp.), dominant (with scores of 0 for EE genotype and 1 for EK and KK genotypes combined), or recessive (with scores of 0 for EE and EK genotypes combined and 1 for KK genotype). The statistical significance was established at $P \leq 0.05$. Bonferroni correction for $P$ values $\left(P_{\text {adj }}\right)$ was applied in cases when multiple tests were performed. Statistical calculations were performed with Statistica for Windows 8.0 (StatSoft Inc., Tulsa, OK, USA).

\section{Results and Discussion}

As can be seen from Table 1, a percentage of positive family history of hypertension and cigarette smokers in the discovery cohort (these data were available only from Kursk population) was significantly greater in patients with $\mathrm{EH}$ versus healthy controls. Body mass index in hypertensives was 
TABLE 2: Allele and genotype frequencies for polymorphism E158K of the FMO3 gene in patients with essential hypertension (EH) and controls in two Russian populations.

\begin{tabular}{|c|c|c|c|c|}
\hline $\begin{array}{l}\text { FMO3 allele and } \\
\text { genotype } \\
\text { frequencies }\end{array}$ & $\begin{array}{l}\text { EH patients } \\
N(\%)^{\mathrm{I}}\end{array}$ & $\begin{array}{l}\text { Controls } \\
N(\%)^{\mathrm{I}}\end{array}$ & $\begin{array}{l}\text { Chi-square } \\
\qquad(P)^{\mathrm{II}}\end{array}$ & $\begin{array}{c}\text { OR } \\
(95 \% \mathrm{CI})\end{array}$ \\
\hline \multicolumn{5}{|c|}{ Discovery cohort (Kursk region), $N=2216$ (1362 EH patients and 843 healthy controls) } \\
\hline \multicolumn{5}{|l|}{ Alleles } \\
\hline $\begin{array}{l}158 \mathrm{E} \\
158 \mathrm{~K}\end{array}$ & $\begin{array}{l}1474(54.1) \\
1250(45.9)\end{array}$ & $\begin{array}{l}960(56.2) \\
748(43.8)\end{array}$ & $\begin{array}{c}1.86(0.17) \\
\mathrm{df}=1\end{array}$ & $1.09(0.96-1.23)^{\mathrm{III}}$ \\
\hline \multicolumn{5}{|l|}{ Genotypes } \\
\hline $\begin{array}{l}158 \mathrm{EE} \\
158 \mathrm{EK} \\
158 \mathrm{KK} \\
\end{array}$ & $\begin{array}{l}423(31.1) \\
628(46.1) \\
311(22.8) \\
\end{array}$ & $\begin{array}{l}260(30.4) \\
440(51.5) \\
154(18.0) \\
\end{array}$ & $\begin{array}{c}9.02(0.01)^{*} \\
\mathrm{df}=2\end{array}$ & $\begin{array}{l}1.35(1.08-1.69)^{\mathrm{III}} \\
1.36(1.09-1.69)^{\mathrm{IV}}\end{array}$ \\
\hline \multicolumn{5}{|c|}{ Replication population (Belgorod region), $N=779$ (357 EH patients and 422 healthy controls) } \\
\hline \multicolumn{5}{|l|}{ Alleles } \\
\hline $\begin{array}{l}158 \mathrm{E} \\
158 \mathrm{~K}\end{array}$ & $\begin{array}{c}365(51.1) \\
349(48.9)\end{array}$ & $\begin{array}{l}468(55.5) \\
476(44.5)\end{array}$ & $\begin{array}{l}2.91(0.09) \\
\mathrm{df}=1\end{array}$ & $1.19(0.97-1.45)^{\mathrm{III}}$ \\
\hline \multicolumn{5}{|l|}{ Genotypes } \\
\hline $\begin{array}{l}158 \mathrm{EE} \\
158 \mathrm{EK} \\
158 \mathrm{KK}\end{array}$ & $\begin{array}{c}105(29.4) \\
155(43.4) \\
97(27.2) \\
\end{array}$ & $\begin{array}{c}127(30.1) \\
214(50.7) \\
81(19.2) \\
\end{array}$ & $\begin{array}{c}7.59(0.02)^{*} \\
\mathrm{df}=2\end{array}$ & $\begin{array}{l}1.57(1.12-2.00)^{\mathrm{III}} \\
1.54(1.07-1.89)^{\mathrm{IV}}\end{array}$ \\
\hline $\begin{array}{l}{ }^{\mathrm{I}} \text { Absolute number an } \\
{ }^{\mathrm{II}} \text { Pearson's chi-squar } \\
{ }^{\mathrm{III}} \text { Odds ratio ( } 95 \% \mathrm{co} \\
{ }^{\mathrm{IV}} \text { Odds ratio ( } 95 \% \mathrm{co} \\
{ }^{*} \text { Means a significant }\end{array}$ & $\begin{array}{l}\text { ndividuals witl } \\
\text { values. } \\
\text { l) for associatio } \\
\text { l) for associatio }\end{array}$ & genotype. & & \\
\hline
\end{tabular}

TABLE 3: The FMO3 genotype cigarette smoking interaction and susceptibility to essential hypertension in Kursk population.

\begin{tabular}{|c|c|c|c|c|c|c|}
\hline \multirow{2}{*}{$\begin{array}{l}\text { FMO3 } \\
\text { genotype }\end{array}$} & \multicolumn{2}{|c|}{$\begin{array}{c}\text { EH patients } \\
N(\%)\end{array}$} & \multicolumn{2}{|c|}{$\begin{array}{c}\text { Controls } \\
N(\%)\end{array}$} & \multicolumn{2}{|c|}{ OR (95\% CI) } \\
\hline & $\begin{array}{l}\text { Smokers } \\
(N=841)\end{array}$ & $\begin{array}{c}\text { Nonsmokers } \\
(N=406)\end{array}$ & $\begin{array}{l}\text { Smokers } \\
(N=483)\end{array}$ & $\begin{array}{c}\text { Nonsmokers } \\
(N=297)\end{array}$ & Smokers & Nonsmokers \\
\hline $158 \mathrm{KK}$ & $198(23.5)$ & $93(22.9)$ & $88(18.2)$ & $57(19.2)$ & $\begin{array}{c}1.38 \\
(1.04-1.83)^{*}\end{array}$ & $\begin{array}{c}1.25 \\
(0.83-1.81) \\
\end{array}$ \\
\hline
\end{tabular}

${ }^{*}$ Means a statistically significant association $(P=0.023)$ after adjustment for multiple tests $\left(P_{\text {adj }}=0.046\right)$.

higher than that in controls in both cohorts, but the difference in this parameter did not reach a statistical significance in Belgorod population (Table 1).

The FMO3 genotype frequencies were in agreement with Hardy-Weinberg equilibrium (HWE) in control groups from both populations $(P>0.05)$. However, the genotype frequencies in hypertensive groups from both Kursk and Belgorod populations showed a deviation from HWE $(P<0.05)$ due to a decreased heterozygosity. Data on allele and genotype frequencies in Kursk and Belgorod populations are shown in Table 2. No significant difference in the allele $158 \mathrm{~K}$ frequency was found between $\mathrm{EH}$ patients and controls in both cohorts. Allele and genotype frequencies were compatible with those reported previously in Kursk population [9]. Meanwhile, a statistically significant difference in the distribution of the FMO3 genotypes was observed between the case and control groups of Kursk population $(P=0.01$, df $=2)$. A statistically significant difference in the distribution of the FMO3 genotypes between the case and control groups was also observed in Belgorod population $(P=0.02)$. The genotype $158 \mathrm{KK}$ was found to be associated with increased risk of hypertension in both Kursk and Belgorod populations after adjustment for gender and age using multiple logistic regression analysis.

Logistic regression analysis revealed that additive (Wald's chi-square $=1.81, P=0.18$ ) and dominant (Wald's chisquare $=0.09, P=0.76)$ genetic models did not show a significant effect of the FMO3 gene polymorphism on hypertension risk. Meanwhile, recessive model of the genetic association between the polymorphism and hypertension risk was established to be statistically significant (Wald's chisquare $=7.28, P=0.007, P_{\text {adj }}=0.02$ ).

Data on the analysis for the FMO3 genotype-cigarette smoking interaction and susceptibility to essential hypertension in Kursk population are shown in Table 3. The genesmoking interaction analysis has revealed that genotype $158 \mathrm{KK}$ was associated with increased risk of hypertension only in smokers $(\mathrm{OR}=1.3895 \%$ CI 1.04-1.83, $P=0.023$, 
$\left.P_{\text {adj }}=0.046\right)$, whereas nonsmoker carriers of the genotype did not show the disease risk (OR $=1.2595 \%$ CI $0.86-1.81$, $P=0.24)$.

We can suggest two possible mechanisms by which the FMO3 gene polymorphism contributes to the development of essential hypertension. Firstly, it is known that an amino acid substitution Glu-to-Lys at a position 158 (i.e., E158K polymorphism) is associated with decreased activity of the enzyme in oxidation of catecholamine releasing agents such as tyramine, phenylethylamine, adrenaline, and noradrenaline possessing vasopressor effects $[6,10]$. This means that the low enzyme activity in carriers of the FMO3 gene variant may be responsible for decreased catabolism of the vasoactive hormones, thereby contributing to hypertension risk through increased vasoconstriction and heart rate modulation. Secondly, a diminished activity of FMO3 in carriers of genotype 158KK may enhance ROS generation and induce oxidative stress, one of the proposed pathogenetic mechanisms of human hypertension $[1,2,11-13]$. Furthermore, we found that cigarette smoking strengthened the risk of essential hypertension in individuals with genotype $158 \mathrm{KK}$. Notably, the effect of tobacco smoking on hypertension risk is mediated through the stimulation of the sympathetic nervous system [14], enhancing ROS generation and oxidative stress [15], that is, processes with which flavin-containing monooxygenase 3 is tightly related.

\section{Conclusions}

The present study demonstrated for the first time that the FMO3 gene polymorphism is associated with susceptibility to essential hypertension, the result which was originally found in Kursk population and then validated in an independent population from Belgorod region. We also observed in the Kursk population that the increased risk of hypertension in carriers of heterozygous genotype $158 \mathrm{KK}$ of the FMO3 gene occurs only in smokers, whereas nonsmokers possessing this genotype do not have the risk of the disease. This finding is an indication of the gene-environment interaction, a situation when adverse effects of cigarette smoking on hypertension can be enhanced by the phenotypic effects of the FMO3 polymorphism. Although much remains to be learned regarding the biological basis of the relationship between the FMO3 gene and hypertension risk, it is already clear that further studies focusing on the investigation of geneenvironment interactions may improve our understanding of the disease pathogenesis and define novel therapeutic and preventive options as a means of personalized medicine in cardiologic practice.

\section{Conflict of Interests}

The authors declare that there is no conflict of interests regarding the publication of this paper.

\section{Acknowledgments}

The study was supported in part by the Federal Targeted Program "Scientific and Scientific-Pedagogical Personnel of the Innovative Russia 2009-2013.” The authors thank Andrey Brezhnev and Ekaterina Vyalykh from Kursk State Medical University and also the clinical staff members of the hospitals for their valuable contribution to the collection of patients for this study.

\section{References}

[1] A. M. Briones and R. M. Touyz, "Oxidative stress and hypertension: current concepts," Current Hypertension Reports, vol. 12, no. 2, pp. 135-142, 2010.

[2] N. F. Renna, "Oxidative stress, vascular remodeling, and vascular inflammation in hypertension," International Journal of Hypertension, vol. 2013, Article ID 710136, 2 pages, 2013.

[3] S. K. Krueger and D. E. Williams, "Mammalian flavincontaining monooxygenases: structure/function, genetic polymorphisms and role in drug metabolism," Pharmacology and Therapeutics, vol. 106, no. 3, pp. 357-387, 2005.

[4] J. R. Cashman, B. R. Akerman, S. M. Forrest, and E. P. Treacy, "Population-specific polymorphisms of the human FMO3 gene: significance for detoxication," Drug Metabolism and Disposition, vol. 28, no. 2, pp. 169-173, 2000.

[5] B. R. Akerman, H. Lemass, L. M. L. Chow et al., "Trimethylaminuria is caused by mutations of the $\mathrm{FMO}_{3}$ gene in a North American cohort," Molecular Genetics and Metabolism, vol. 68, no. 1, pp. 24-31, 1999.

[6] C. Dolan, D. C. Shields, A. Stanton et al., "Polymorphisms of the flavin containing monooxygenase 3 (FMO3) gene do not predispose to essential hypertension in Caucasians," $B M C$ Medical Genetics, vol. 6, article 41, 2005.

[7] A. V. Polonikov, V. P. Ivanov, M. A. Solodilova et al., "A common polymorphism G-50T in cytochrome P450 2J2 gene is associated with increased risk of essential hypertension in a Russian population," Disease Markers, vol. 24, no. 2, pp. 119-126, 2008.

[8] I. N. Sorokina, M. I. Churnosov, and E. V. Balanovskaia, "The gene pool of the Belgorod region population: description of the "genetic landscape" of 22 district populations," Genetika, vol. 45, no. 5, pp. 700-710, 2009.

[9] E. K. Vialykh, M. A. Solodilova, O. Y. Bushueva, I. V. Bulgakova, and A. V. Polonikov, "Catalase gene polymorphism is associated with increased risk of cerebral stroke in hypertensive patients," Zhurnal Nevrologii i Psihiatrii imeni S.S. Korsakova, vol. 112, no. 8, part 2, pp. 3-7, 2012.

[10] E. P. Treacy, B. R. Akerman, L. M. L. Chow et al., "Mutations of the flavin-containing monooxygenase gene (FMO3) cause trimethylaminuria, a defect in detoxication," Human Molecular Genetics, vol. 7, no. 5, pp. 839-845, 1998.

[11] R. M. Touyz, "Oxidative stress and vascular damage in hypertension," Current Hypertension Reports, vol. 2, no. 1, pp. 98-105, 2000.

[12] J. de Champlain, R. Wu, H. Girouard et al., "Oxidative stress in hypertension," Clinical and Experimental Hypertension, vol. 26, no. 7-8, pp. 593-601, 2004.

[13] N. D. Vaziri and B. Rodríguez-Iturbe, "Mechanisms of disease: oxidative stress and inflammation in the pathogenesis of hypertension," Nature Reviews Nephrology, vol. 2, no. 10, pp. 582-593, 2006. 
[14] A. Virdis, C. Giannarelli, M. F. Neves, S. Taddei, and L. Ghiadoni, "Cigarette smoking and hypertension," Current Pharmaceutical Design, vol. 16, no. 23, pp. 2518-2525, 2010.

[15] M. A. H. Talukder, W. M. Johnson, S. Varadharaj et al., "Chronic cigarette smoking causes hypertension, increased oxidative stress, impaired NO bioavailability, endothelial dysfunction, and cardiac remodeling in mice," The American Journal of Physiology-Heart and Circulatory Physiology, vol. 300, no. 1, pp. H388-H396, 2011. 


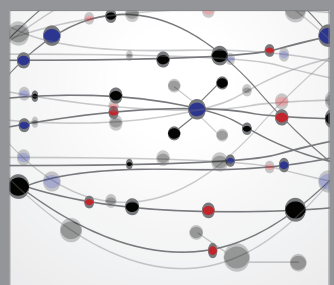

The Scientific World Journal
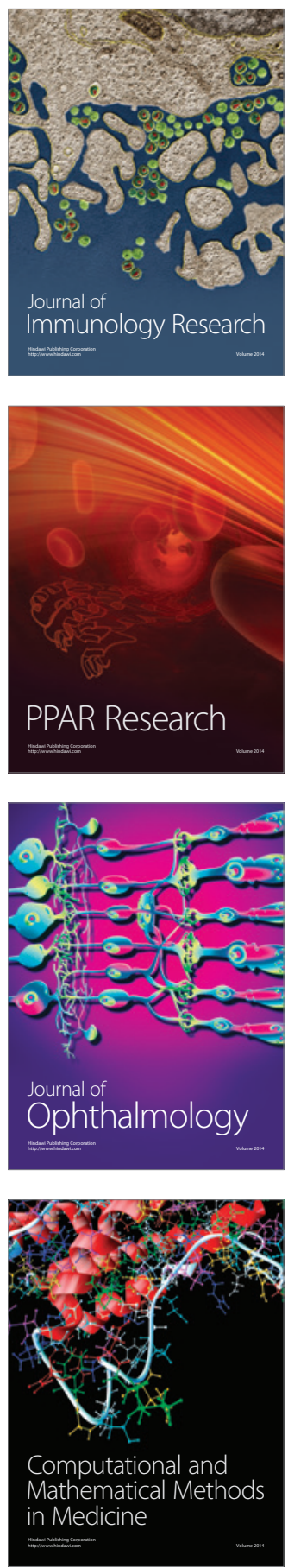

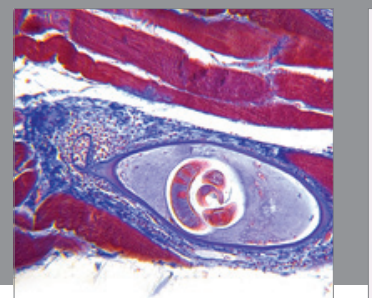

Gastroenterology

Research and Practice
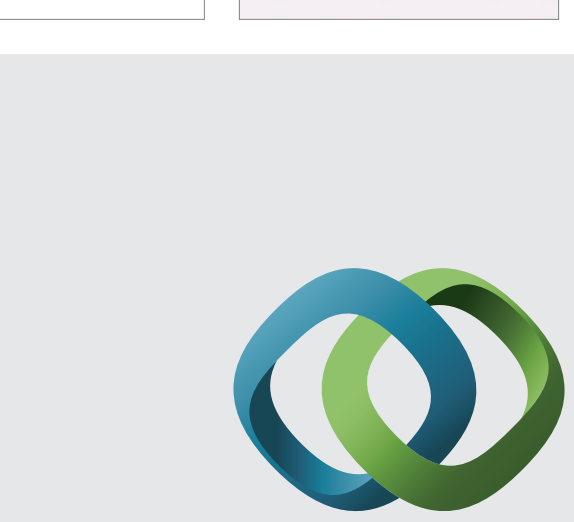

\section{Hindawi}

Submit your manuscripts at

http://www.hindawi.com
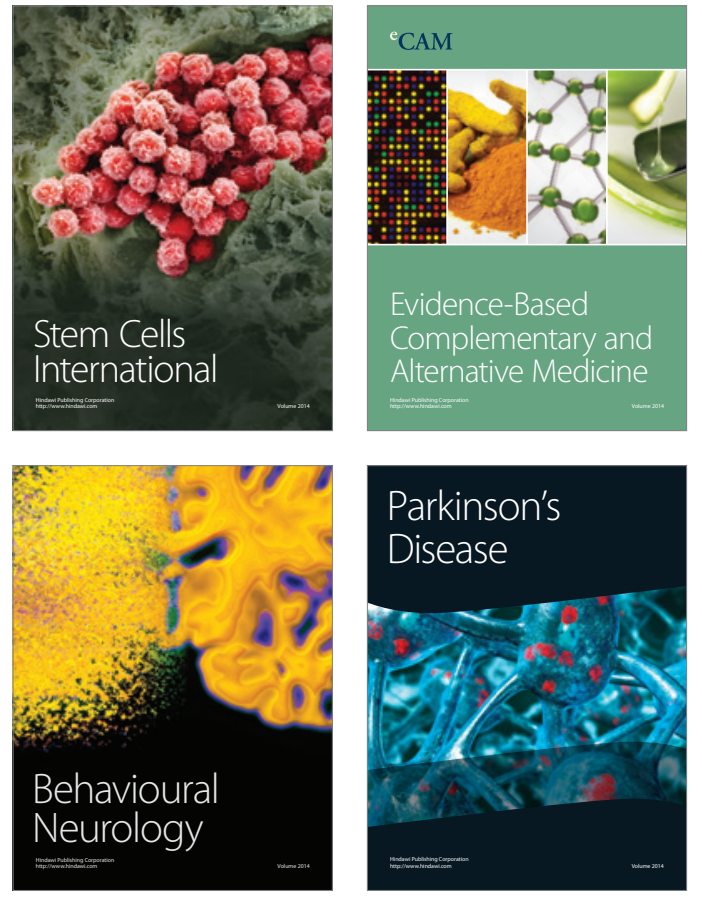
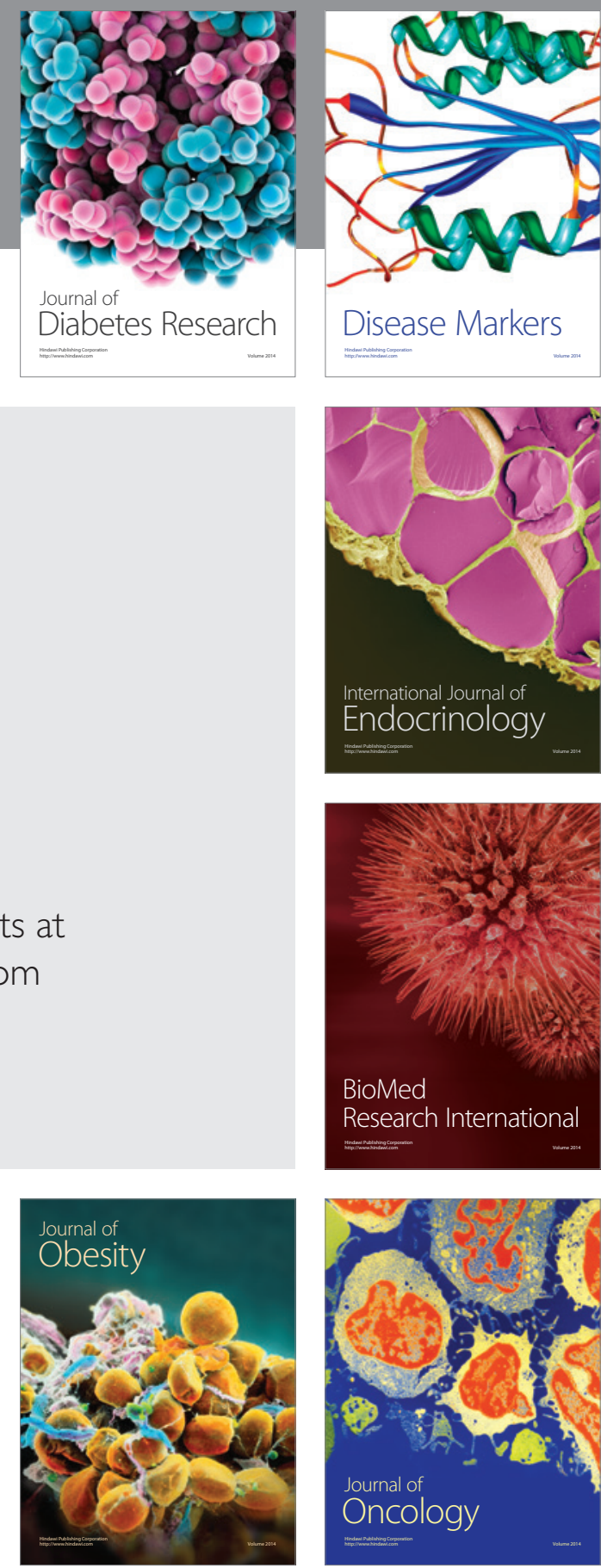

Disease Markers
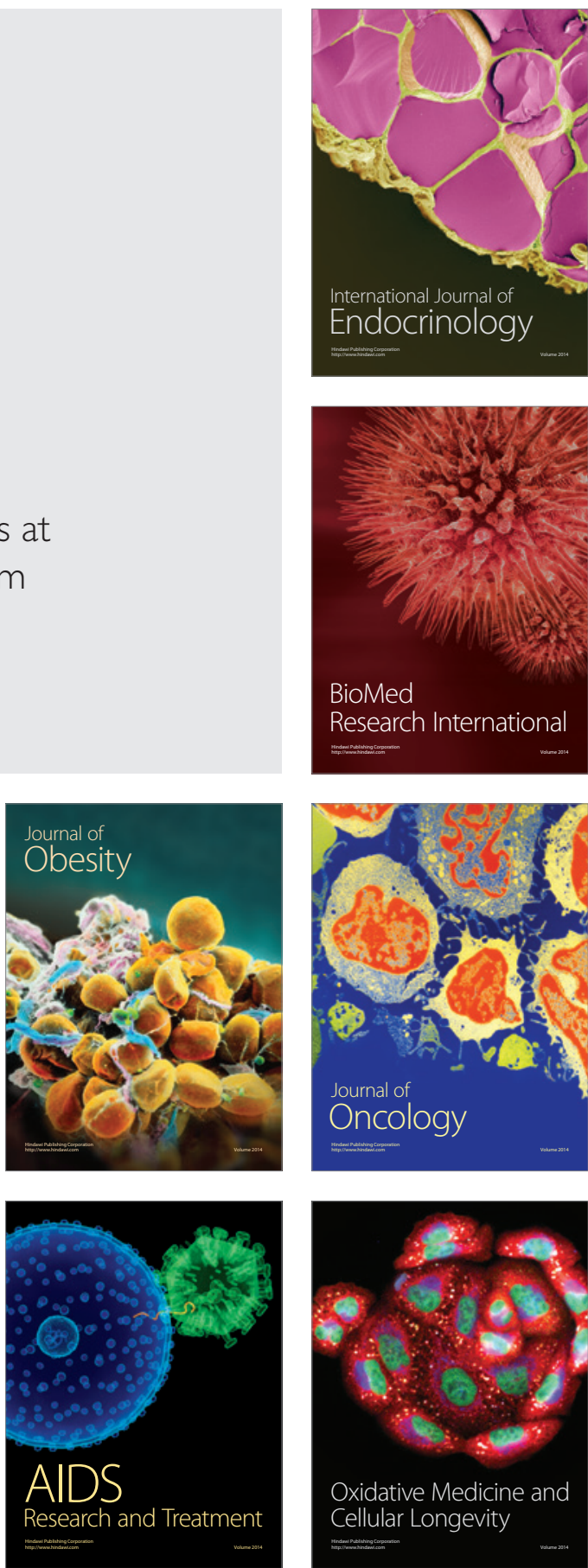